\title{
DEMOKRASI DALAM PANDANGAN YUSUF AL- QARADHAWI
}

\author{
M. Alwin Abdillah \\ Dosen Fakultas Syariah IAIN Langsa
}

\begin{abstract}
Abstrak
Tema demokrasi adalah salah satu tema yang sampai saat ini masih menarik untuk didiskusikan. Berbagai karya yang mengulas tentang demokrasi telah dihasilkan — baik itu oleh para pemikir Islam maupun Barat. Semenjak kedatangan bangsa Barat ke dunia Islam, dan seiring dengan kemajuan bangsa Barat saat ini, maka sesuatu yang datang dari Barat selalu dijadikan indikator symbol kemajuan. Atas klaim itu sehingga banyak negara merasa penting untuk "mencontoh" - baik secara langsung atau tidak — segala bentuk kemajuan yang pernah dicapai oleh Barat-termasuk di dalamnya tema demokrasi.
\end{abstract}

Kata Kunci: Demokrasi, Demokrasi Dalam Pandangan Islam

\begin{abstract}
The theme of democracy is one of the themes that is still interesting to discuss. Various works that deal with democracy have been produced - both by Islamic thinkers and Westerners. Since the arrival of the West to the Islamic world, and along with the progress of the West today, then something that comes from the West has always been an indicator of progress. For this claim so that many countries feel it is important to "follow" - whether directly or indirectly - all forms of progress that have been achieved by the West - including the theme of democracy.
\end{abstract}

Keyword: Democratic, Islamic Law

\section{PENDAHULUAN}

Di Indonesia telah banyak menganut sistem pemerintahan pada awalnya. Namun, dari semua sistem pemerintahan, yang bertahan mulai dari era reformasi 1998 sampai saat ini adalah sistem pemerintahan demokrasi. Meskipun masih terdapat beberapa kekurangan dan tantangan disana sini. Sebagian kelompok merasa merdeka dengan diberlakukannya sistem domokrasi di Indonesia. Artinya, kebebasan pers sudah menempati ruang yang sebebas-bebasnya sehingga setiap orang berhak menyampaikan pendapat dan aspirasinya masing-masing.

Demokrasi merupakan salah satu bentuk atau mekanisme sistem pemerintahan suatu negara sebagai upaya mewujudkan kedaulatan rakyat atau 
negara yang dijalankan oleh pemerintah. Semua warga negara memiliki hak yang setara dalam pengambilan keputusan yang dapat mengubah hidup mereka. Demokrasi mengizinkan warga negara berpartisipasi baik secara langsung atau melalui perwakilan dalam perumusan, pengembangan, dan pembuatan hukum.

Demokrasi mencakup kondisi social, ekonomi, dan budaya yang memungkinkan adanya praktik kebebasan politik secara bebas dan setara.

Demokrasi Indonesia dipandang perlu dan sesuai dengan pribadi bangsa Indonesia. Selain itu yang melatar belakangi pemakaian sistem demokrasi di Indonesia. Hal itu bisa kita temukan dari banyaknya agama yang masuk dan berkembang di Indonesia, selain itu banyaknya suku, budaya dan bahasa, kesemuanya merupakan karunia Tuhan yang patut kita syukuri.

\section{Pengertian Demokrasi}

Demokrasi berasal dari bahasa Yunani "Demokratia" yang berarti kekuasaan rakyat. Demokrasi berasal dari kata "Demos" dan "Kratos". Demos yang memiliki arti rakyat dan Kratos yang memiliki arti kekuasaan. Menurut Kamus

\footnotetext{
${ }^{1)}$ Georg Sorensen, Demokrasi and Demokratization: Processed and Prospects in a Changing Word, Trj. I. Made Krisna,
}

Besar Bahasa Indonesia (KBBI)

Demokrasi adalah gagasan atau pandangan hidup yang mengutamakan persamaan hak dan kewajiban serta perlakuan yang sama bagi semua warga negara. Berikut ini adalah pengertian demokrasi menurut beberapa ahli ${ }^{1}$ :

1. Demokrasi menurut Montesque, kekuasaan negara harus dibagi dan dilaksanakan oleh tiga lembaga atau institusi yang berbeda dan terpisah satu sama lainnya, yaitu pertama, legislatif yang merupakan pemegang kekuasaaan untuk membuat undangundang, kedua, eksekutif yang memiliki kekuasaan dalam melaksanakan undang-undang, dan ketiga adalah yudikatif, yang memegang kekuasaan untuk mengadili pelaksanaan undangundang. Dan masing-masing institusi tersebut berdiri secara independen tanpa dipengaruhi oleh institusi lainnya.

2. Demokrasi menurut Abraham Lincoln yaitu pemerintahan dari rakyat, oleh rakyat, dan untuk rakyat.

3. Demokrasi menurut Aristoteles mengemukakan ialah suatu kebebasan atau prinsip demokrasi ialah kebebasan, karena hanya

Demokrasi dan Demokratisasi (Proses dan Prospek Dalam Sebuah Dunia yang Sedang Berubah, Yogyakarta : Pustaka Pelajar, 2003, h. 15 
melalui kebebasanlah setiap warga negara bisa saling berbagi kekuasaan didalam negaranya. Aristoteles pun mengatakan apabila seseorang hidup tanpa kebebasan dalam memilih cara hidupnya, maka sama saja seperti budak.

4. Demokrasi menurut H. Harris Soche ialah suatu bentuk pemerintahan rakyat, karenanya kekuasaan pemerintahan melekat pada rakyat juga merupakan HAM bagi rakyat untuk mempertahankan, mengatur dan melindungi diri dari setiap paksaan dalam suatu badan yang diserahkan untuk memerintah.

5. Demokrasi menurut International Commission of Juris adalah bentuk pemerintahan dimana hak dalam membuat suatu keputusan politik harus diselenggarakan oleh rakyat melalui para wakil yang terpilih dalam suatu proses pemilu.

\section{Prinsip Demokrasi}

Prinsip demokrasi dibedakan menjadi dua, yaitu ${ }^{2}$ :

1. Prinsip Demokrasi Sebagai Sistem Politik a. Pembagian kekuasaan (kekuasaan legislatif, yudikatif, dan eksekutif)

b. Pemerintahan konstitusional

c. Partai politik lebih dari satu dan mampu melaksanakan fungsinya

d. Pers yang bebas

e. Perlindungan terhadap hak asasi manusia

f. Pengawasan terhadap administrasi negara

g. Peradilan yang bebas dan tidak memihak

h. Pemerintahan yang diskusi

i. Pemilihan umum yang bebas.

j. Pemerintahan berdasarkan hukum

2. Prinsip Non-demokrasi (Kediktatoran)

a. Pemusatan kekuasaan

Kekuasaan legislatif, eksekutif dan yudikatif menjadi satu dan dipegang serta dijalankan oleh satu lembaga.

b. Pemerintahan tidak berdasarkan konstitusional

Pemerintahan dijalankan berdasarakan kekuasaan. Konstitusinya memberi kekuasaan yang besar pada negara atau pemerintah.

\footnotetext{
2) A. Ubaidillah, et al, Pendikan Kewarganegaraan (civil education) Demokrasi, Hak Asasi Manusia, dan Masyarakat Madani, Jakarta: ICCE UIN Syarif Hidayatullah , 2000, h. 39.
} 
c. Rule of Power

Prinsip negara kekuasaan yang ditandai dengan supremasi kekuasaan yang besar pada negara atau pemerintah..

d. Pembentukan pemerintah tidak berdasarkan musyawarah tetapi melalui dekrit

e. Pemilihan umum yang tidak demokratis.

Pemilihan umum dijalankan hanya untuk memperkuat keabsahan penguasa atau pemerintah negara.

f. Manajemen dan kepemimpinan yang tertutup dan tidak bertanggung jawab. Tidak ada dan atau dibatasinya kebebasan berpendapat, berbicara dan kebebasan pers.

g. Penyelesaian perpecahan atau perbedaan dengan cara kekerasan dan penggunaan paksaan.

h. Tidak ada perlindungan terhadap hak asasi manusia bahkan sering terjadi pelanggaran hal asasi manusia.

i. Menekan dan tidak mengakui hak- hak minoritas warga negara.

\section{Jenis-jenis Demokrasi}

Demokrasi memiliki banyak jenisnya. Berikut beberapa jenis dari demokrasi ${ }^{3}$ :

a. Demokrasi menurut cara aspirasi rakyat

b. Demokrasi Langsung Merupakan sistem demokrasi yang memberikan kesempatan kepada seluruh warga negaranya dalam permusyawaratan saat menentukan arah kebijakan umum dari negara atau undangundang.

c. Demokrasi Tidak Langsung Merupakan sistem demokrasi yang dijalankan menggunakan sistem perwakilan.

d. Demokrasi Berdasarkan Prinsip Ideologi

e. Demokrasi Liberal Merupakan Kebebasan individu yang lebih ditekankan dan mengabaikan kepentingan umum

\footnotetext{
3) Henry. B. Mayo, "Nilai-nilai Demokrasi", dalam Miriam Budiardjo (Ed.), Masalah Kenegaraan, Jakarta: Gramedia, 1975, h. 159-196.
} 
f. Demokrasi Rakyat

Merupakan demokrasi yang

didasarkan pada paham

sosialisme dan komunisme dan

lebih

mengutamakan

kepentingan umum atau negara.

g. Demokrasi Pancasila

Merupakan demokrasi yang ada

di Indonesia bersumberkan pada

nilai- nilai sosial budaya bangsa

serta berazaskan musyawarah

mufakat

dengan

memprioritaskan kepentingan

seluruh msyarakat atau warga

negara. Demokrasi pancasila

fokus pada kepentingan dan

aspirasi serta hati nurani rakyat.

Sampai saat ini Indonesia

menganut demokrasi pancasila

yang bersumber pada falsafah

pancasila.

\section{Ciri-Ciri Demokrasi}

Ciri yang menggambarkan suatu pemerintahan didasarkan oleh sistem demokrasi seperti:

- Pemerintahan didasarkan kehendak dan kepentingan semua rakyat.

- Ciri konstitusional ialah hal yang berhubungan denag kepentingan, kehendak atau kemauan atau kekuasaan rakyat

yang dituliskan dalam

konstitusi dan undang-

undang negara tersebut.

- Ciri perwakilan yakni dalam mengatur negaranya kedaulatan rakyat akan diwakilkan oleh beberapa orang yang sudah dipilih oleh rakyat itu sendiri.

- Ciri pemilihan umum yakni sebuah kegiatan politik yang dilaksanakan untuk memilih pihak dalam pemerintahan.

- Ciri kepartaian yakni partai akan menjadi media atau sarana untuk menjadi bagian dalam melaksanakan sistem demokrasi.

- Ciri kekuasaan ialah adanya pembagian dan pemisah kekuasaan.

- Ciri tanggung jawab ialah adanya tanggung jawab dari pihal yang sudah dipilih untuk ikut dalam pelaksaan suatu sistem demokrasi. 


\section{DEMOKRASI DALAM PANDANGAN} ISLAM.

Menurut Al-Maududi, beliau secara tegas menolak demokrasi. Menurut nya Islam tidak mengenal paham demokrasi yang memberikan kekuasaan besar kepada rakyat untuk menetapkan segala hal, demokrasi adalah buatan manusia sekaligus produk dari pertentangan Barat terhadap agama sehingga cendrung sekuler. Karenanya Al-Maududi mengganggap demokrasi modern (Barat) merupakan sesuatu yang bersifat syirik. Menurutnya Islam menganut paham teokrasi (berdasarkan hukum Tuhan). Tentu saja bukan teokrasi yang diterapkan di Barat pada abad pertengahan yang telah memberikan kekuasaan tak terbatas pada para pendeta. ${ }^{4}$

Selanjutnya prinsip Demokrasi menurut Sadek J. Sulayman, dalam demokrasi terdapat sejumlah prinsip yang menjadi standar baku di antaranya: 1) Kebebasan berbicara setiap warga Negara ${ }^{5}$

Pelaksanaan pemilu untuk menilai apakah pemerintah yang berkuasa layak didukung kembali atau harus diganti; 3) Kekuasaan dipegang oleh suara mayoritas

\footnotetext{
4 Idris Thaha, Demokrasi Religius Pemikiran Politik Nurcholis Madjid dan Amien Rais, , Bandung: Mizan Publika, 2005, h. 24
}

tanpa mengabaikan kontrol minoritas; 4) Peranan partai politik yang sangat penting sebagai wadah aspirasi politik rakyat; 5) Pemisahan kekuasaan legislatif, eksekutif dan yudikatif; 6) Supremasi Hukum (semua harus tunduk pada hokum); 7) Semua individu bebas melakukan apa saja tanpa boleh dibelenggu.

Kritikan terhadap demokrasi yang berkembang juga dikatakan oleh intelektual Pakistan ternama yaitu M.Iqbal, menurut beliau sejalan dengan kemenangan sekularisme atas nama demokrasi modern menjadi kehilangan sisi spritualnya sehingga jauh dari etika. Demokrasi yang merupakan kekuasaan dari rakyat oleh rakyat untuk rakyat telah mengabaikan keberadaan agama.

Parlemen sebagai salah satu pilar demokrasi dapat saja menetapkan hukum yang bertentangan dengan nilai agama kalau anggotanya menghendaki. Karenanya menurut Iqbal Islam tidak dapat menerima model demokrasi Barat yang telah kehilangan basis moral dan spiritual. Atas dasar itu, Iqbal menawarkan sebuah konsep demokrasi spiritual yang dilandasi oleh etik dan moral ketuhanan. Jadi yang ditolak oleh Iqbal bukan demokrasi an sich, melainkan prakteknya yang berkembang di Barat. Lalu Iqbal menawarkan sebuah

\footnotetext{
5 Jaih Mubarok, Fiqh Siyasah, StudiTentang Ijtihad dan Fatwa Politik di Indonesia, Bandung: Pustaka Bani Quraisy, 2005, h. 50.
} 
model demokrasi sebagai berikut: 1) Tauhid sebagai landasan asasi; 2) Kepatuhan pada hukum; 3) Toleransi sesama warga; 4) Tidak dibatasi wilayah, ras dan warna kulit; 5) Penafsiran hukum Tuhan melalui ijtihad.

Menurut Muhammad Imarah, Islam tidak menerima demokrasi secara mutlak dan juga tidak menolaknya secara mutlak. Dalam demokrasi kekuasaan legislative (membuat dan menetapkan hokum) secara mutlak berada di tangan rakyat. Sementara dalam sistem syura (Islam) kekuasaan tersebut merupakan wewenang Allah. Dialah pemegang kekuasaan hukum tertinggi. Wewenang manusia hanyalah menjabarkan dan merumuskan hokum sesuai dengan prinsip yang digariskan Tuhan serta berijtihad untuk sesuatu yang tidak diatur oleh ketentuan Allah. Jadi Allah berposisi sebagai Al-Syari (legislator) sementara manusia berposisi sebagai faqih (yang memahami dan menjabarkan) hukumNya. Demokrasi Barat berpulang pada pandangan mereka tentang batas kewenangan Tuhan. Menurut Aristoteles setelah Tuhan menciptakan alam, Dia membiarkanya. Dalam filsafat Barat manusia memiliki kewenangan legislatif dan eksekutif. Sementara dalam pandangan Islam, Allah lah pemegang otoritas tersebut. Allah berfirman dalam (surat Al-Araf: 54). Ingatlah menciptakan dan memerintah hanyalah hak Allah, Maha suci Allah Tuhan semesta alam. Inilah batasan yang membedakan antara sistem syariah Islam dan Demokrasi Barat. Adapun hal lainnya seperti membangun hukum atas persetujuan umat, pandangan mayoritas, serta orientasi pandangan umum dan sebagainya adalah sejalan dengan Islam.

Rasyid Al-Ghanoushi dan Abdul Fattah Morou, kedua tokoh Gerakan Kecenderungan Islam (Movement de Tendence Islamique/ MTI), mereka mengkombinasikan ajaran Islam dengan demokrasi. Bagi Ganaoshi, demokrasi , kedaulatan rakyat, dan peran negara ("negara bukan berasal dari Tuhan melainkan dari rakyat . . . negara harus melayani kepentingan kaum Muslim"), pemilihan umum, multi partai, dan undang-undang adalah bagian pemikiran baru Islam yang akar dan legitimasinya di dapatkan dari interprestasi atau reinterpretasi yang segar dari sumbersumber Islam. Sedangkan bagi Morou, "hukum berasal dari Tuhan tetapi kedaulatan adalah dari rakyat". Ia membedakan antara prinsip-prinsip umum Al-Qur'an yang mampu bertahan dan legislasi manusia dalam batasan prinsip- 
prinsip tersebut yang menjadi tanggung jawab rakyat. ${ }^{6}$

Ali abd al-Raziq tidak menolak tesis yang menyatakan bahwa Nabi Muhammmad Saw. Adalah pemimpin secara sosiologis dan agama. Akan tetapi yang ia tolak adalah tesis yang menyatakan bahwa Nabi Muhammad adalah kepala negara. Tesis ini ditolak karena kepala negara adalah kepemimpinan duniawi yang disatukan oleh ikatan politik, sedangkan kepemimpinan Nabi Saw. Adalah ikatan agama yang berdimensi duniawi dan ukhrawi. Ketika Nabi Saw. Bertindak duniawi melakukan perang, damai, memperlakukan tawanan, menumpas pemberontak adalah tindkan yang merupakan media dakwah untuk menyukseskan misi risalahnya, bukan karena kedudukan sebagai pemimpin politik. $^{7}$

Pemikiran demokrasi substantif dalam pandangan Nahdlatul Ulama, di antaranya adalah: 1) Masyarakat mempunyai hak yang sama, kesetaraan; 2) Kebebasan berekspresi dalam Islam dijadikan landasan untuk reinterpretasi, konsesnsus ulama, perbedaan pendapat,

\footnotetext{
${ }^{6}$ Sukron Kamil, Islam dan Demokrasi, Telaah Konseptual dan Historis, Jakarta: Gaya Media Pratama,2002, h. 49

7 Ali 'Abd. Al-Raziq dengan gagasannya yang menolak bahwa Nabi saw. sebagai pemimpin politik, akhirnya dikucilkan oleh dewan ulama al-azhar dan tidak boleh
}

kemaslahatan umat, dan akuntabilitas public; 3) Keadilan, dalam Islam perintah berbuat adil sangat banyak kita temukan dalam firman Allah; 4) Toleransi. Sikap ini merupakan dasar dalam menghargai agama lain. Lakum dinukum waliyadin, Untukmu agamamu dan untukku agamaku; 5) Musyawarah dalam pengambilan keputusan: sebagai bukti bahwa Indonesia adalah Negara demokrasi antara lain dan terutama adalah adanya pemilihan umum.

Demokrasi berarti kedaulatan yang berada di tangan rakyat. Dengan kata lain, kedaulatan rakyat mengandung pengertian bahwa sistem kekuasaan tertinggi dalam sebuah Negara dibawah kendali rakyat. Pengertian bahwa sistem kekuasaan tertinggi dalam sebuah Negara dibawah kendali rakyat . Adapun unsur penegak yang mendukung berdirinya sebuah demokrasi yaitu Negara hukum, masyarakat madani, infrastuktur politik, dan pers yang bebas dan bertanggung jawab. Sudah sepantasnya kita sebagai negara yang berdemokrasi bisa menghargai pendapat orang lain. Kita sebagai warga Negara harus ikut menciptakan Negara yang berdemokrasi.

memangku jabatan apapun dalam pemerintahan. Lihat: Ali 'Abd. Al-Raziq, "Kekhilafahan dan Dasar-Dasar Kekuasaan", dalam John J. Donohue dan John L. Esposito (Ed.), Islam dan Pembaharuan: Ensiklopedi MasalahMasalah, Jakarta: PT.RajaGrafindo Persada, 1994, h. 39. 
Dan sebagai warga yang baik, seharusnya kita harus menyikapi demokrasi ini dengan perbuatan yang positif, bukan menyikapinya dengan anarkis, money politic dan tidak bertanggung jawab. Jadi, kita harus meningkatkan kedewasaan dalam berpolitik, bertanggung jawab dan mematuhi segala aturan yang ada pada kehidupan demokrasi. Dan kita berharap Indonesia dapat menjadikan Negara yang maju dan lebih baik lagi dalam segala hal. ${ }^{8}$

Demokrasi Dalam Pandangan Yusuf AlQaradhawi

Yusuf al-Qaradhawi mendukung demokrasi seraya berpendapat bahwa demokrasi merupakan alternatif terbaik untuk diktatorisme dan pemerintahan tirani. Berikut ini ringkasan pendapat Dr. Yusuf al-Qaradhawi mengenai demokrasi disertai dengan komentar terhadapnya.

Yusuf al-Qaradhawi mengatakan: "Sesungguhnya sisi liberalisme demokrasi yang paling baik menurut saya adalah sisi politiknya, yang tercermin dalam penegakan kehidupan perwakilan, di dalamnya rakyat dapat memilih wakilwakil mereka yang akan memerankan kekuasaan legislatif di parlemen, dan di dalam satu majelis atau dua majelis.
Pemilihan ini hanya bisa ditempuh melalui pemilihan umum yang bebas dan umum, dan yang berhak menerima adalah yang mendapat suara paling banyak dari para calon yang berafiliasi ke partai politik atau non-partai.

"Kekuasaan yang terpilih" inilah yang akan memiliki otoritas legislatif untuk rakyat, sebagaimana ia juga mempunyai kekuasaan untuk mengawasi kekuasaan eksekutif atau "pemerintah", menilai, mengkritik, atau menjatuhkan mosi tidak percaya, sehingga dengan demikian, kekuasaan eksekutif tidak lagi layak untuk dipertahankan

Dengan kekuasaan yang terpilih, maka semua urusan rakyat berada di tangannya, dan dengan demikian, rakyat menjadi sumber kekuasaan.

Bentuk ini secara teoritis cukup baik dan dapat diterima, menurut kaca mata Islam secara garis besar, jika dapat diterapkan secara benar dan tepat, serta dapat dihindari berbagai keburukan dan hal-hal negatif yang terdapat padanya.Saya katakan "secara garis besar", karena pemikiran Islam memiliki beberapa kewaspadaan terhadap beberapa bagian tertentu dari bentuk di atas.

Kekuasaan terpilih itu tidak memiliki penetapan hukum untuk hal-hal

\footnotetext{
8 Aden Widjan SZ, dkk, Pemikiran dan Peradaban Islam, Yogyakarta: Safaria, Insania Press, 2007, h.203.
} 
yang tidak diizinkan oleh Allah Ta'ala. Kekuasaan ini juga tidak boleh menghalalkan yang haram atau mengharamkan yang halal atau menggugurkan suatu kewajiban. Sebab, yang mempunyai kekuasaan menetapkan hukum satu-satunya hanyalah Allah jalla Sya'nuhu.

Manusia hanya boleh membuat hukum untuk diri mereka sendiri dalam hal yang diizinkan Allah Ta'ala saja. Artinya, hukum yang mengatur kepentingan dunia mereka yang tidak dimuat di dalam suatu nash tertentu, atau nash yang mengandung beberapa makna kemudian mereka memilih salah satu makna dan menggunakannya dengan memperhatikan kaidah-kaidah syari'at. Dalam hal itu terdapat medan yang sangat luas sekali bagi para pembuat undang-undang.

Di sana terdapat dua sifat yang disyaratkan Islam bagi setiap orang yang akan mengemban suatu pekerjaan.

Pertama: Mampu mengemban pekerjaan ini dan mempunyai pengalaman di bidangnya Kedua: Amanah. Dengan sifat amanah inilah suatu pekerjaan akan terpelihara dan pelakunya akan takut kepada Allah Ta'ala. Itulah yang diungkapkan oleh al-Qur'an melalui lisan Yusuf Alaihissallam, di mana dia mengatakan:

9) Yusuf al - Qardhawi, Al- Hulul al mustarida wa Kifa Janat Ummatuna, Muasasah Risalah, Cetakan ke lima, 1993, h. 640

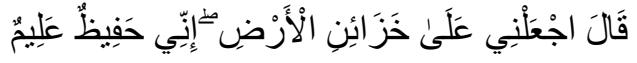

"Berkata Yusuf, jadikanlah aku bendaharawan negara (Mesir); sesungguhnya aku adalah orang yang pandai menjaga lagi berpengetahuan." ${ }^{9}$ [Yusuf /12: 55]

Juga dalam kisah Musa Alaihissallam, melalui lisan puteri seorang yang sudah tua renta:

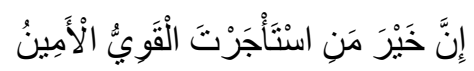

"Karena sesungguhnya, orang yang paling baik yang kamu ambil untuk bekerja (pada kita) ialah orang yang kuat lagi dapat dipercaya. " 10 [Al-Qashash/28 : 26]

Dengan demikian, kekuatan dan ilmu memerankan sisi intelektual dan profesional yang menjadi syarat suatu pekerjaan, sedangkan kemampuan menjaga dan amanat mencerminkan sisi moral dan mental yang memang dituntut pula untuk keberhasilannya. ${ }^{11}$

Dr. Yusuf al-Qaradhawi mengungkapkan: "Anehnya, sebagian orang memvonis demokrasi sebagai suatu yang jelas-jelas merupakan bentuk kemungkaran atau bahkan kekufuran yang nyata, sedang mereka belum memahaminya secara baik dan benar sampai kepada

\footnotetext{
10) Yusuf Qardhawi, Fataawa 'Mu'aashirah, h.643.

11) Yusuf Qardhawi, Fataawa 'Mu'aashirah,, h.644 - 645.
} 
substansinya tanpa memandang kepada bentuk dan cirinya.

Di antara kaidah yang ditetapkan oleh para ulama terdahulu adalah, bahwa keputusan (hukum) terhadap sesuatu merupakan bagian dari pemahamannya. Oleh karena itu, barangsiapa menghukumi sesuatu yang tidak diketahuinya, maka hukumnya adalah salah, meskipun secara kebetulan bisa benar. Sebab, ibaratnya ia merupakan lemparan yang tidak disengaja. Oleh karena itu, di dalam hadits ditetapkan bahwa seorang hakim yang memberi keputusan dengan didasarkan pada ketidaktahuan, maka dia berada di neraka, sebagaimana orang yang mengetahui yang benar, tetapi dia menetapkan atau menghukumi dengan yang lain.

Lalu apakah demokrasi yang didengung-dengungkan oleh berbagai bangsa di dunia, dan diperjuangkan oleh banyak orang, baik di dunia belahan barat maupun timur, di mana ada sebagian bangsa bisa sampai kepadanya setelah melalui berbagai pertempuran sengit dengan penguasa tirani, yang menelan banyak darah dan menjatuhkan ribuan bahkan jutaan korban manusia. Sebagaimana yang terjadi di Eropa timur dan lain-lainnya, dan yang banyak dari pemerhati Islam menganggapnya sebagai sarana yang bisa diterima untuk meruntuhkan kekuasaan monarki, serta memotong kukukuku politik campur tangan, yang telah banyak menimpa masyarakat muslim. Apakah demokrasi ini mungkar atau kafir, sebagaimana yang didengungkan oleh beberapa orang yang tidak memahami sepenuhnya lagi tergesagesa!!?!”

Sesungguhnya substansi demokrasi -tanpa definisi dan istilah akademis- adalah memberikan kesempatan kepada rakyat untuk memilih orang yang akan mengurus dan mengendalikan urusan mereka, sehingga mereka tidak dipimpin oleh penguasa yang tidak mereka sukai, atau diatur oleh sistem yang mereka benci. Selain itu, mereka juga harus mempunyai hak menilai dan mengkritik jika penguasa melakukan kesalahan, juga hak opsi jika penguasa melakukan penyimpangan, dan rakyat tidak boleh digiring kepada aliran atau sistem ekonomi, sosial, kebudayaan, atau politik yang tidak mereka kenal dan tidak pula mereka setujui. Jika sebagian mereka menghalanginya, maka balasannya adalah pemecatan atau bahkan penyiksaan dan pembunuhan."12

Sesungguhnya Islam telah mendahului sistem demokrasi dengan menetapkan beberapa kaidah yang menjadi

${ }^{12) Y u s u f ~ Q a r d h a w i, ~ F a t a a w a ~ ' M u ' a a s h i r a h, ~ h .649 . ~}$ 
pijakan substansinya, tetapi Islam menyerahkan berbagai rinciannya kepada ijtihad kaum muslimin sesuai dengan pokok-pokok agama mereka, kepentingan dunia mereka, serta perkembangan kehidupan mereka sesuai dengan zaman dan tempat, dan juga pembaharuan keadaan manusia.

Kelebihan demokrasi adalah, bahwa ia mengarahkan di sela-sela perjuangannya yang panjang melawan kezhaliman dan kaum tirani serta para raja kepada beberapa bentuk dan sarana, yang sampai sekarang dianggap sebagai jaminan yang paling baik untuk menjaga rakyat dari penindasan kaum tirani.

Tidak ada larangan bagi umat manusia, para pemikir dan pemimpin mereka untuk memikirkan bentuk dan cara lain, barangkali cara baru itu akan mengantarkan kepada yang lebih baik dan ideal. Tetapi, untuk mempermudah kepada hal tersebut dan merealisasikannya ke dalam realitas manusia, kita melihat bahwa kita harus mengambil beberapa hal dari cara-cara demokrasi guna mewujudkan keadilan, permusyawaratan, penghormatan hak-hak asasi manusia, serta berdiri melawan kesewenangan para penguasa yang angkuh di muka bumi ini.

Di antara kaidah syari'at yang ditetapkan adalah, bahwa sesuatu yang menjadikan hal yang wajib tidak sempurna kecuali dengannya, maka ia itu menjadi wajib, dan bahwasanya tujuantujuan syari'at yang diharapkan adalah jika tujuantujuan itu mempunyai sarana pencapaiannya, maka sarana ini boleh diambil sebagai alat menggapai tujuan tersebut.

Tidak ada satu syari'at pun yang melarang penyerapan pemikiran teori atau praktek empiris dari kalangan non-muslim. Karena, Nabi Shallallahu 'alaihi wa sallam sendiri pada perang Ahzab telah mengambil pemikiran "penggalian parit", padahal strategi tersebut berasal dari strategi bangsa Parsi.

Selain itu, Rasulullah Shallallahu 'alaihi wa sallam pernah juga mengambil manfaat dari tawanan musyrikin dalam perang Badar "dari orang-orang yang mampu membaca dan menulis" untuk mengajarkan baca tulis anak-anak kaum muslim.in, meski mereka itu musyrik. Dengan demikian, hikmah itu adalah barang temuan orang mukmin, di mana saja dia menemukannya, maka dia yang paling berhak atasnya.

Dalam beberapa buku, saya telah mengisyaratkan bahwa merupakan hak kita untuk mengambil manfaat dari pemikiran, strategi dan sistem yang bisa memberikan manfaat kepada kita, selama tidak bertentangan dengan nash muhkam (yang jelas) dan tidak juga kaidah syari'at yang 
sudah baku, dan kita harus memilih dari apa yang kita ambil untuk selanjutnya menambahkannya dan melengkapinya dengan bagian ruh kita serta hal-hal yang dapat menjadikannya sebagai bagian dari kita dapat dan menghilangkan identitas pertamanya." $" 13$

Ungkapan seseorang yang mengatakan, bahwa demokrasi berarti kekuasaan rakyat oleh rakyat dan karenanya, harus ditolak prinsip yang menyatakan, bahwa kekuasaan itu hanya milik Allah semata, maka ungkapan semacam itu sama sekali tidak dapat diterima.

Bagi para penyeru demokrasi tidak perlu harus menolak kekuasaan Allah atas manusia. Hal seperti itu tidak pernah terbersit di dalam hati mayoritas penyeru demokrasi. Tetapi yang menjadi konsentrasi mereka adalah menolak kediktatoran yang sewenang-wenang, serta menolak pemerintahan otoriter terhadap rakyat.

Benar, setiap yang dimaksudkan dengan demokrasi oleh mereka adalah memilih pemerintah oleh rakyat sesuai dengan hati nurani mereka, serta memantau tindakan dan kebijakan mereka, serta menolak berbagai perintah mereka jika bertentangan dengan undang undang

13) Yusuf Qardhawi, Fataawa 'Mu'aashirah, h.650.

${ }^{14}$ )Yusuf Qardhawi, Fataawa 'Mu'aashirah, h.650. rakyat, atau dengan ungkapan Islam: “Jika mereka memerintahkan untuk berbuat maksiat," dan mereka juga mempunyai hak untuk menurtmkan penguasa jika melakukan penyimpangan dan berbuat zhalim serta tidak mau menerima nasihat atau peringatan." 14

Sesungguhnya undang-undang menetapkan, di samping berpegang pada demokrasi, bahwa agama negara adalah Islam dan bahwasanya syari'at Islam adalah sumber hukum dan undangundang, dan yang demikian itu merupakan penegasan akan kekuasaan Allah atau kekuasaan syari'at-Nya, dan kekuasaan itulah yang memiliki kalimat tertinggi.

Dimungkinkan juga untuk menambahkan pada undang-gundang materi yang secara tegas dan lantang menetapkan, bahwa setiap undang-undang atau sistem yang bertentangan dengan syari'at yang baku dan permanen, maka undang-undang itu adalah bathil." 15

Tidak ada ruang untuk pemberian suara dalam berbagai hukum pasti dari syari'at dan juga pokok-pokok agama serta halhal yang wajib dilakukan dalam agama, tetapi pemberian suara itu pada masalah-masalah ijtihadiyah yang mencakup lebih dari satu pendapat. Sudah menjadi kebiasaan manusia untuk berbeda pendapat dalam hal

\footnotetext{
${ }^{15}$ )Yusuf Qardhawi, Fataawa 'Mu'aashirah, Jilid II, h.670.
} 
tersebut, misalnya pemilihan salah satu calon yang akan menempati suatu jabatan, meskipun itu jabatan kepala negara, dan seperti juga pengeluaran undang-undang untuk mengatur lalu lintas jalan raya atau untuk mengatur bangunan tempat perdagangan atau industri atau rumah sakit, atau yang lainnya yang oleh para ahli fiqih disebut sebagai "mashalihul mursalah." Atau seperti juga pengambilan keputusan untuk mengumumkan perang atau tidak, mengharuskan pembayaran pajak tertentu atau tidak, atau mengumumkan keadaan darurat atau tidak, atau membatasi jabatan Presiden, dan pembolehan membatasi masa pemilihan atau tidak, demikian seterusnya.

Jika banyak pendapat yang berbeda dalam masalah ini, maka apakah pendapat itu akan ditinggal menggantung begitu saja, apakah ada tarjih tanpa murajjah (yang diunggulkan)? Ataukah harus ada murajjah?

Sesungguhnya logika akal, syari'at dan realitas menyatakan harus ada murajjah (yang diunggulkan), dan yang diunggulkan pada saat terjadi perbedaan pendapat adalah jumlah terbanyak. Sebab, pendapat dua orang itu lebih mendekati kebenaran daripada pendapat satu orang, dan dalam hadits disebutkan:

"Sesungguhnya, syaitan itu bersama satu orang dan dia (syaitan) lebih jauh dari dua orang."

Ungkapan orang yang menyatakan, bahwa tarjih (pengunggulan satu pendapat) itu adalah untuk yang benar meskipun tidak ada seorang pun pendukungnya. Adapun yang salah harus ditolak meskipun didukung oleh 99 dari 100. Ungkapan ini hanyalah tepat pada hal-hal yang ditetapkan oleh syari'at secara gamblang, tegas dan terang yang menyingkirkan perselisihan dan tidak mengandung perbedaan atau menerima pertentangan, dan hal itu hanya sedikit sekali. Itulah yang dikatakan: Jama'ah itu adalah yang sejalan dengan kebenaran meski engkau hanya sendirian.

Sesungguhnya petaka pertama yang menimpa umat Islam dalam perjalanan sejarahnya adalah sikap mengabaikan terhadap kaidah musyawarah, dan perubahan "Khilafah Rasyidah" menjadi "kerajaan penindas" yang oleh sebagian sahabat disebut "kekaisaran". Artinya, kekuasaan absolut Kaisar telah berpindah kepada kaum muslimin dari berbagai kerajaan yang telah diwariskan Allah kepadanya. Padahal semestinya mereka mengambil pelajaran dari mereka dan menghindari berbagai kemaksiatan dan perbuatan hina yang menjadi sebab musnahnya negara mereka.

Apa yang menimpa Islam, umatnya, serta dakwahnya di zaman modern ini tidak 
lain adalah akibat dari pemberlakuan pemerintahan otoriter yang bertindak sewenang wenang terhadap umat manusia dengan menggunakan pedang kekuasaan dan emasnya, dan tidaklah syari'at dihapuskan, skularisme diterapkan, serta umat manusia diharuskan berkiblat ke barat melainkan dengan paksaan, memakai besi dan api. Tidaklah dakwah Islam dan gerakannya dipukul habis-habisan serta tidak juga para penganut dan penyerunya dihajar dan dikejar-kejar melainkan oleh kekuasaan otoriter yang terkadang tanpa kedok dan terkadang dengan menggunakan kedok demokrasi palsu yang diperintahkan oleh kekuatan yang memusuhi lslam secara terang-terangan atau diarahkan dari balik layar."16

Di sini saya (Dr. Yusuf alQaradhawi) perlu menekankan, bahwa saya bukan termasuk orang yang suka menggunakan kata-kata asing, seperti misalnya; demokrasi dan lain-lainnya untuk mengungkapkan pengertian-pengertian Islam.

Tetapi, jika suatu istilah telah menyebar luas di tengah-tengah umat manusia dan telah dipergunakan oleh banyak orang, maka kita tidak perlu menutup pendengaran kita darinya, tetapi kita harus mengetahui maksud istilah

\footnotetext{
${ }^{16)}$ Yusuf Qardhawi, Fataawa 'Mu'aashirah, Jilid II, h.675.

${ }^{17}$ )Yusuf Qardhawi, Fataawa 'Mu'aashirah, Jilid II, h.677.
}

tersebut, sehingga kita tidak memahaminya secara keliru, atau mengartikannya secara tidak benar atau yang tidak dikehendaki oleh orang-orang yang membicarakannya, dengan begitu hukum kita terhadapnya adalah hukum yang benar dan seimbang. Meski istilah itu datang dari luar kalangan kita, hal itu tidak menjadi masalah. Sebab, poros hukum itu tidak pada nama dan sebutan, tetapi pada kandungan dan substansinya." $" 17$

Saya (Dr. Yusuf al-Qaradhawi) termasuk orang yang menuntut demokrasi dalam posisinya sebagai sarana yang sangat mudah dan teratur untuk merealisasikan tujuan kita dalam kehidupan yang mulia, yang di dalamnya kita bisa berdakwah kepada Allah dan juga kepada Islam, sebagaimana kita telah beriman kepadanya, tanpa harus dijebloskan ke dalam penjara yang gelap atau dihukum di atas tiang gantungan." 18

Berkenaan dengan hal tersebut, dapat penulis katakan: "Dr. Yusuf alQaradhawi telah dengan sekuat tenaga membela demokrasi dalam menghadapi pemerintahan otokrasi atau pemerintahan tirani yang berbagai keburukan dan kesialannya telah dirasakan oleh Dr.Yusuf al-Qaradhawi dan Jama'ah Ikhwanul Muslimin. Oleh karena itu, Dr. Yusuf al-

${ }^{18}$ )Yusuf Qardhawi, Fataawa 'Mu'aashirah, Jilid II, h.680. 
Qaradhawi berusaha keras mempertahankan demokrasi dengan segenap daya dan upaya.

Yang lebih baik dilakukan oleh Dr. Yusuf al-Qaradhawi adalah, menegakkan hukum Islam yang di dalamnya terdapat konsep musyawarah Islami yang sudah cukup bagi kita dan tidak lagi memerlukan demokrasi ala Barat meskipun kita memolesnya dengan berbagai kebaikan dan keindahan.

Jika kita menyaring demokrasi ini, lalu menambahkan beberapa hal yang sesuai dengan agama kita atau mengurangi beberapa hal darinya yang memang bertentangan dengan agama, lalu mengapa kita harus menyebutnya demokrasi? Mengapa tidak menyebutnya syura (permusyawaratan) misalnya.

Dengan demikian, demokrasi Barat tidak disebut demikian kecuali diambil dengan seluruh kandungannya. Tetapi, jika diambil dengan melakukan penyesuaian, perubahan dan penyimpangan, maka hal itu secara otomatis menjadi sesuatu yang lain yang tidak mungkin kita sebut lagi sebagai demokrasi. Dalam hal ini, perumpamaannya adalah sama dengan khamr jika rusak dengan sendirinya atau tindakan

19) Bagi yang berminat menambah pengetahuan tentang masalah demokrasi ini sekallgus mengetahui sisi-sisi negatif dan keburukannya, hendaklah ia membaca risalah al-Islamiyyuun wa Saraabud Demoqrathiyyah karya Abdul Ghani (telah diterjemahkan kedalam bahasa Indonesia : Fenomena Demokrasi, Studi Analisis Perpolitikan Dunia Islam oleh Abdul Ghany bin Muhammad Ar-rahhal -ed), Haqiiqatud Demoqrathiyyah seseorang, maka pada saat itu tidak lagi disebut sebagai khamr, tapi disebut cuka. Demikian pula demokrasi.

Jadi, yang harus dilakukan oleh Dr. Yusuf al-Qaradhawi adalah menyeru kepada penegakan hukum Islam dengan menerapkan sistem syura (permusyawaratan) yang adil, daripada mengobati suatu penyakit dengan penyakit lain, yang bisa jadi lebih berbahaya lagi bagi umat. ${ }^{19}$

\section{KESIMPULAN}

Menurut Yusuf Al-Qardhawi, menurut beliau substansi demokrasi sejalan dengan Islam, hal ini bisa dilihat dari beberapa hal misalnya: Dalam demokrasi proses pemilihan melibatkan banyak orang untuk mengangkat seorang kandidat yang berhak memimpin dan mengurus keadaan mereka. Tentu saja mereka tidak boleh memilih sesuatu yang tidak mereka sukai. Demikian juga dengan Islam, Islam menolak seseorang menjadi imam sholat yang tidak disukai oleh makmum di belakangnya. Usaha setiap rakyat untuk meluruskan penguasa yang tirani juga sejalan dengan Islam. Bahkan amar makruf

karya Muhammad Syakir asy-Syarif, ad-Demoqrathryyah fil Miizaan karya Sa'id Abdul Azhim dan Khamsuuna Mafsadah jaliyyah min Mafasidid Demoqrathiyyah karya 'Abdul Majid ar-Riimi. 
dan nahi mungkar serta memberikan nasihat kepada pemimpin adalah bagian dari ajaran Islam. 


\section{DAFTAR PUSTAKA}

Aden Widjan SZ, dkk, Pemikiran dan Peradaban Islam, Yogyakarta: Safaria, Insania Press, 2007

Ali “Abd. Al-Raziq, “Kekhilafahan dan Dasar-Dasar Kekuasaan”, dalam John J. Donohue dan John L. Esposito (Ed.), Islam dan Pembaharuan: Ensiklopedi MasalahMasalah, Jakarta: PT.RajaGrafindo Persada, 1994

DR. Yusuf al - Qardhawi, Al- Hulul al mustarida wa Kifa Janat Ummatuna, Muasasah Risalah, Cetakan ke lima, 1993

DR. Yusuf Qardhawi, Fataawa 'Mu'aashira

Georg Sorensen, Demokrasi and Demokratization: Processed and Prospectsin a Changing Word, Trj. I. Made Krisna, Demokrasi dan Demokratisasi (Proses dan Prospek Dalam Sebuah Dunia yang Sedang Berubah, Yogyakarta : Pustaka Pelajar, 2003

Henry. B. Mayo, "Nilai-nilai Demokrasi”, dalam Miriam Budiardjo (Ed.), Masalah Kenegaraan, Jakarta: Gramedia, 1975

Idris Thaha, Demokrasi Religius Pemikiran Politik Nurcholis Madjid dan Amien Rais, , Bandung: Mizan Publika, 2005

Jaih Mubarok, Fiqh Siyasah, StudiTentang Ijtihad dan Fatwa Politik di Indonesia, Bandung: Pustaka Bani Quraisy, 2005

Sukron Kamil, Islam dan Demokrasi, Telaah Konseptual dan Historis, Jakarta: Gaya Media Pratama,2002

Ubaidillah, et al, Pendikan Kewarganegaraan (civil education) Demokrasi, Hak Asasi Manusia, dan Masyarakat Madani, Jakarta: ICCE UIN Syarif Hidayatullah , 2000 